\title{
Targeting the proinflammatory cytokine tumor necrosis factor- $\alpha$ to alleviate cardiopulmonary bypass-induced lung injury (Review)
}

\author{
MINGXIN GAO ${ }^{1,2^{*}}$, BAODONG XIE $^{3 *}$, CHENGXIONG GU $^{1}$, HAITAO LI $^{1}$, FAN ZHANG $^{1}$ and YANG YU ${ }^{1}$ \\ ${ }^{1}$ Department of Cardiac Surgery, Beijing An Zhen Hospital, Capital Medical University, Beijing 100029; \\ ${ }^{2}$ Beijing Institute of Heart Lung and Blood Vessel Diseases, Beijing 100029; ${ }^{3}$ Department of Cardiovascular Surgery, \\ The Second Affiliated Hospital of Harbin Medical University, Harbin, Heilongjiang 150086, P.R. China
}

Received February 7, 2014; Accepted November 12, 2014

DOI: $10.3892 / \mathrm{mmr} .2014 .3050$

\begin{abstract}
Pulmonary dysfunction is one of the most frequent complications associated with cardiopulmonary bypass (CPB). Multiple factors, including the contact of blood with the artificial surface of the CPB circuit, ischemia-reperfusion and lung ventilator arrest elicit inflammatory reactions, consequently resulting in CPB-induced lung injury. The proinflammatory cytokine tumor necrosis factor- $\alpha$ (TNF- $\alpha$ ) has been demonstrated to have a critical role in mediating CPB-induced pulmonary inflammation. The present review evaluated previous studies and summarized the effects of CPB on TNF- $\alpha$ level in the serum and lung tissue of patients and animal models of $\mathrm{CPB}$, the underlying mechanism of TNF- $\alpha$-mediated lung injury and the therapeutic strategies for the inhibition of TNF- $\alpha$ activity and production to attenuate CPB-induced lung injury. TNF- $\alpha$ level in the serum and lung tissue is significantly increased during and following CPB. TNF- $\alpha$ mediates CPB-induced lung damage by directly inducing apoptosis in alveolar epithelial cells and lung endothelial cells and by indirectly modulating the function of immune cells, including monocytes and macrophages. A functional neutralizing antibody to TNF- $\alpha$ can reduce pulmonary TNF- $\alpha$ production and attenuate CPB-induced lung injury in a rabbit model of CPB. Inhibition of TNF- $\alpha$ function and production using a neutralizing antibody to TNF- $\alpha$ appears to be a promising therapeutic strategy to alleviate CPB-induced lung injury.
\end{abstract}

Correspondence to: Dr Yang Yu, Department of Cardiac Surgery, Beijing An Zhen Hospital, Capital Medical University, 2 An Zhen Road, Beijing 100029, P.R. China

E-mail: heartyuyang@hotmail.com

*Contributed equally

Key words: cardiopulmonary bypass, tumor necrosis factor- $\alpha$, lung injury

\section{Contents}

1. Introduction

2. The underlying mechanism of TNF- $\alpha$-mediated lung injury during $\mathrm{CPB}$

3. Therapeutic strategies targeting TNF- $\alpha$ to attenuate CPB-induced lung injury

4. Effects of anti-inflammatory intervention on TNF- $\alpha$ level

5. Conclusion

\section{Introduction}

Postoperative pulmonary dysfunction is one of the most common complications associated with cardiopulmonary bypass $(\mathrm{CPB})$ and it is particularly associated with an increased morbidity and mortality in high-risk patients having repeat coronary artery bypass surgery (1). The clinical presentation of CPB-induced lung injury varies from mild dyspnea to fully developed adult respiratory distress syndrome in $\sim 2 \%$ of cases undergoing $\mathrm{CPB}$, which, in itself, results in a $50 \%$ mortality rate $(2,3)$. The damaged lung following $\mathrm{CPB}$ is characterized by abnormal functional, physiological, biochemical and histological alterations, including abnormal gas exchange and poor lung mechanics, increased lung permeability and pulmonary vascular resistance, the presence of neutrophil elastase and high expression of matrix metalloproteinases (MMPs) as well as alveolar edema and extravasation of erythrocytes and neutrophils (4).

Although impairment of lung function can occur following any major surgery, CPB appears to cause additional damage to the lung compared with off-pump coronary artery bypass grafting (5). It has been well recognized that the contact of blood cells with the artificial surface of the CPB circuit can activate polymorphonuclear cells (PMNs) and PMN activity can be further enhanced by proinflammatory factors (6), suggesting increased inflammation associated with CPB. Furthermore, ischemia-reperfusion also significantly contributes to CPB-induced inflammation. Diegeler et al (7) observed a significantly increased release of activated complement factors C5a and C3d, interleukin (IL)- 8 and IL-10 and prolonged elevation of tumor necrosis factor- $\alpha$ (TNF- $\alpha$ ) receptors p55 and p75 in patients undergoing CPB compared with 
the off-pump groups. In addition, postoperative white blood cell, neutrophil and monocyte counts and oxidative stress are also significantly higher in the on-pump than the off-pump group $(8,9)$. Thus, CPB appears to be able to elicit or exasperate a series of inflammatory reactions, ultimately leading to lung injury. The purpose of this review was to discuss the therapeutic strategies for reducing CPB-induced pulmonary inflammation with a particular focus on the intervention approaches targeting the proinflammatory cytokine TNF- $\alpha$.

\section{The underlying mechanism of TNF- $\alpha$-mediated lung injury during CPB}

Effects of $C P B$ on TNF- $\alpha$ level in the serum and lung tissue. Numerous studies on clinical CPB and animal models of CPB have demonstrated that the serum levels of proinflammatory cytokines, including IL-1, IL-2, IL-4, IL-6, IL-8 and TNF- $\alpha$ are significantly increased during and following CPB (7-13). Wan et al (13) summarized the cytokine responses during clinical CPB and illustrated the complexity and diversity of the $\mathrm{CPB}$-induced cytokine response. The present review aimed to focus on the proinflammatory cytokine TNF- $\alpha$.

Studies on the effects of CPB on the serum level of TNF- $\alpha$ in patients are controversial. Zhang et al (10) revealed that the serum level of TNF- $\alpha$ in patients undergoing $\mathrm{CPB}$ significantly increases when $\mathrm{CPB}$ begins and reaches a maximum following CPB. By contrast, Welters et al (14) and Martínez-Comendador et al (15) reported that the plasma level of TNF- $\alpha$ is not statistically different pre- and post-surgery. The discrepancy may be due to the different trial design and different experimental procedure in these studies and also the complex chemistry of TNF- $\alpha$ in solution. The diverse baseline of TNF- $\alpha$ in different patients, which is associated with the unique genetic background of each individual may also contribute to this discrepancy. Previous studies have demonstrated that circulating TNF- $\alpha$ level in patients correlates with TNF- $\alpha$ polymorphisms. Boehm et al (16) analyzed two polymorphisms from the promoter region of the TNF- $\alpha$ gene, TNF- $\alpha-863$ C/A and TNF- $\alpha-308$ G/A. They revealed significant associations of the TNF- $\alpha 863 \mathrm{CC}$ variant with higher TNF- $\alpha$ level preoperatively, following CPB and $6 \mathrm{~h}$ postoperatively, while the TNF- $\alpha 863$ AA allele correlated with lower TNF- $\alpha$ level at all time points. Compared with the TNF- $\alpha 863$ C/A polymorphism, fewer significant associations were detected between the TNF- $\alpha 308 \mathrm{G} / \mathrm{A}$ polymorphism and TNF- $\alpha$ level. The patients with the TNF- $\alpha 308 \mathrm{GG}$ allele have lower TNF- $\alpha$ level immediately following CPB, whereas TNF- $\alpha 308$ AA carriers are significantly associated with elevated TNF- $\alpha$ level preoperatively and immediately following CPB (16). Studies on the association between TNF- $\alpha 308$ G/A polymorphism and serum level of TNF- $\alpha$ by other groups demonstrate varying results. Yoon et al (17) demonstrated that the TNF- $\alpha 308$ AA variant correlated with increased TNF- $\alpha$ level, while Galiñanes et al (18) did not detect any correlation.

In animal models of CPB in which the genetic background of the experimental animal is more uniform than in humans, including rabbit, piglet and rat models, it is consistently observed that the serum level of TNF- $\alpha$ is significantly increased during and following CPB $(11,12,19,20)$. Notably,
Qi et al (11) demonstrated that in a rabbit model of CPB, in addition to a significant increase of systemic levels of TNF- $\alpha$, the serum level of TNF- $\alpha$ from the left atrium is significantly higher than that from the right atrium (Table I). Furthermore, TNF- $\alpha$ mRNA level in lung tissue is also increased markedly during $\mathrm{CPB}$, suggesting that $\mathrm{CPB}$ can induce pulmonary TNF- $\alpha$ synthesis and release (11), which could further exasperate $\mathrm{CPB}$-induced lung injury.

TNF- $\alpha$ mediates lung injury during CPB. Although direct clinical evidence demonstrating that TNF- $\alpha$ can cause lung damage during and following CPB remains lacking, the association between increased level of TNF- $\alpha$ and pulmonary dysfunction has been indicated in multiple studies. Dauber et al revealed that peak circulating TNF levels correlate with $\mathrm{CPB}$-induced coronary and pulmonary vascular injury (21). Studies on a rabbit model of CPB demonstrated that endotracheal administration or pulmonary perfusion of a neutralizing antibody against TNF- $\alpha$ significantly reduced pulmonary edema and alleviated histological damage in the lung $(11,12)$. In a rat model, TNF- $\alpha$ markedly induced pulmonary vascular barrier dysfunction with increased lung water content and impaired oxygenation (22).

The molecular and cellular mechanisms underlying TNF- $\alpha$-mediated lung injury remain to be elucidated. As a proinflammatory cytokine, TNF- $\alpha$ has been revealed to not only directly induce apoptosis in pulmonary endothelial and alveolar epithelial cells but also trigger a cascade of immune reactions to damage lung function indirectly. Petrache et al used bovine pulmonary artery endothelial cells to investigate the molecular mechanism underlying TNF- $\alpha$-induced endothelial cell apoptosis and barrier dysfunction (23). They demonstrated that TNF- $\alpha$ significantly enhanced apoptosis and stimulated the formation of stress fibers and paracellular gaps by increasing myosin light chain (MLC) phosphorylation through MLC kinase and Rho kinase, which consequently resulted in the reduction of transcellular electrical resistance (23). Wang et al (24) demonstrated that human TNF- $\alpha$ induces dose-dependent apoptosis in pulmonary alveolar epithelial cells derived from the human lung carcinoma cell line A549 and primary cultures of well-differentiated type II alveolar epithelial cells from the rat. TNF- $\alpha$-induced apoptosis requires the induction of angiotensinogen expression, proteolytic processing of the synthesized angiotensinogen protein and the subsequent binding of angiotensin II to its receptor.

At the cellular level, TNF- $\alpha$ has been found to activate and recruit PMNs $(25,26)$. The activated PMNs secrete proteolytic enzymes, including MMPs and elastase and release oxygen-free radicals into the systemic circulation and lung tissue (25). Consequently, this leads to the degradation of pulmonary ultrastructure and permeabilization of pulmonary alveolar cells and endothelium. It has also been demonstrated that TNF- $\alpha$ can regulate the immune capacity of monocytes and macrophages by regulating the expression of toll-like receptors (TLRs). Tsai et al (26) used human monocytic THP-1 cells to elucidate that TNF- $\alpha$ can downregulate TLR4 expression and induce intracellular tristetraprolin (TTP) expression through the mitogen-activated protein kinase (MAPK)/extracellular-signal regulated kinase signaling pathway (Fig. 1). Their results from in vitro tissue culture are consistent with 
Table I. TNF- $\alpha$ level in blood samples (pg/l).

\begin{tabular}{|c|c|c|c|c|c|c|c|c|c|}
\hline \multirow[b]{2}{*}{ Group } & \multicolumn{2}{|c|}{ Prior to $\mathrm{CPB}$} & \multirow[b]{2}{*}{ P-value } & \multicolumn{3}{|c|}{5 min after aortic clamp release } & \multicolumn{2}{|c|}{ CPB termination } & \multirow[b]{2}{*}{ P-value } \\
\hline & Right atr & Left & & Righ & Lef & P-value & Right & Le & \\
\hline I & $104.40 \pm 14.17$ & 111.5 & $\mathrm{P}>0.05$ & 116. & 116 & $\mathrm{P}>$ & 1 & 11 & $\mathrm{P}>0.05$ \\
\hline II & $110.14 \pm 48.32$ & $94.45 \pm 37.18$ & $\mathrm{P}>0.05$ & $240.37 \pm 56.44^{\mathrm{a}}$ & $329.24 \pm 69.99$ & $\mathrm{P}<0.05$ & $208.25 \pm 39.15^{\mathrm{a}}$ & 257. & $\mathrm{P}<0.05$ \\
\hline III & $110.61 \pm 38.22$ & $108.25 \pm 22.90$ & $P>0.05$ & $236.73 \pm 41.92^{\mathrm{a}}$ & $319.74 \pm 48.11$ & $\mathrm{P}<0.05$ & $207.35 \pm 52.11^{\mathrm{a}}$ & $266.65 \pm 40.23$ & $\mathrm{P}<0.05$ \\
\hline IV & $110.49 \pm 47.56$ & $113.63 \pm 33.05$ & $\mathrm{P}>0.05$ & $212.98 \pm 55.30^{\mathrm{a}}$ & $215.49 \pm 56.28$ & $\mathrm{P}>0.05$ & $189.84 \pm 37.09^{\mathrm{a}}$ & $192.79 \pm 39.43$ & $\mathrm{P}>0.05$ \\
\hline
\end{tabular}

Group I, open chest operation only; Groups II, CPB only; Group III, CPB+endotracheal intubation with phosphate-buffered saline; Group IV, $\mathrm{CPB}+$ endotracheal intubation with TNF- $\alpha$ antibody $(2,400 \mathrm{pg} / \mathrm{kg})$. P-values were obtained by the comparison of the right and left atriums in each group as compared with group I, ${ }^{a} \mathrm{P}<0.05$ (11). CBP, cardiopulmonary bypass; TNF- $\alpha$, tumor necrosis factor- $\alpha$.

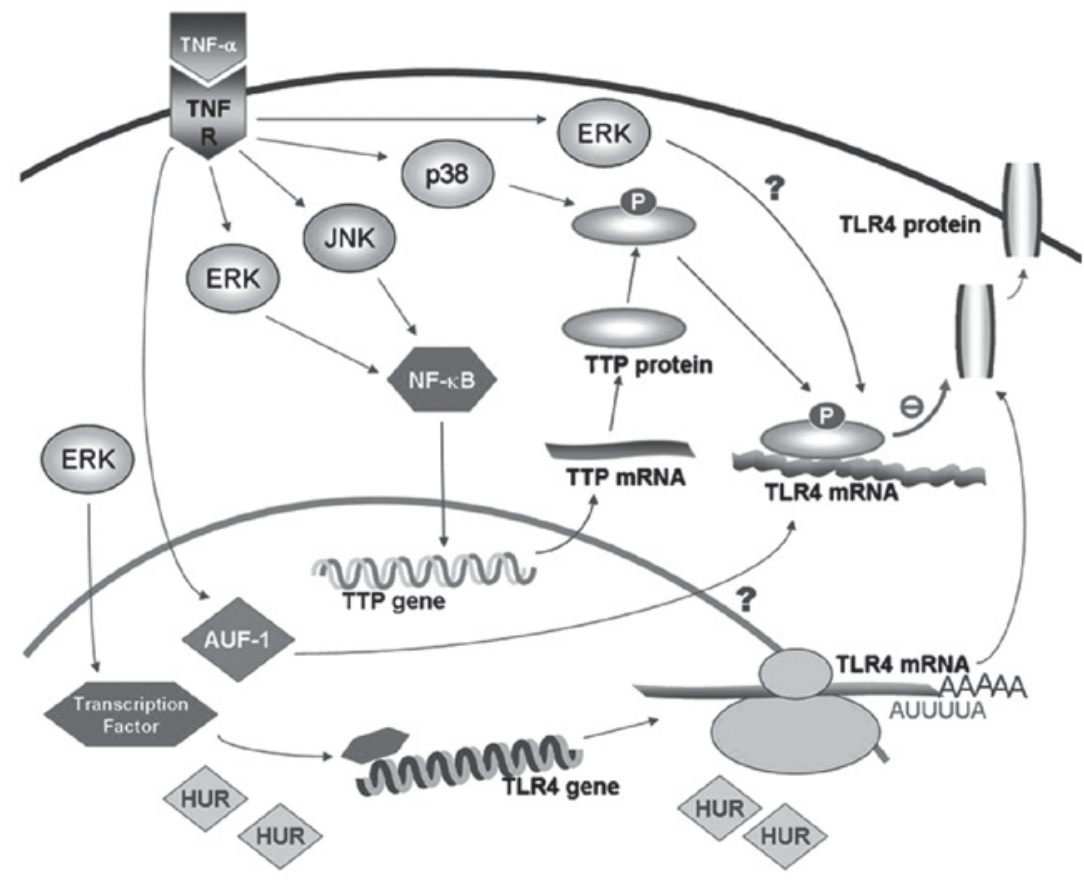

Figure 1. Mechanism underlying TNF- $\alpha$ mediates downregulation of TLR4 expression in monocytic cells. TNF- $\alpha$ and CPB cause MAPK-dependent activation and expression of TTP. ERK1/2 and JNK/SAPK-dependent TTP gene expression and subsequent p38 MAPK-dependent phosphorylation of TTP contribute to TLR4 downregulation of TNF- $\alpha$-stimulated monocytes (26). TNF- $\alpha$, tumor necrosis factor- $\alpha$; CPB, cardiopulmonary bypass; TLR, toll-like receptor; ERK, extracellular-signal regulated kinase; NF-кB, nuclear factor-кB; MAPK, mitogen-activated protein kinase; JNK/SAPK, c-Jun NH2-terminal kinase/stress-activated protein kinase; TTP, tristetraprolin; AUF-1, AU-rich element RNA-binding protein 1.

the observation of clinical samples, which demonstrate that TTP expression increases and TLR4 expression decreases in monocytes following CPB (26).

\section{Therapeutic strategies targeting TNF- $\alpha$ to attenuate CPB-induced lung injury}

Inhibition of $T N F-\alpha$ production. It has been revealed that $\mathrm{p} 38$ MAPK is involved in regulating TNF- $\alpha$ transcription (27). Thus, inhibition of p38 MAPK may be an effective approach to reduce TNF- $\alpha$ production. Dong et al pretreated rats using intravenous administration of the specific p38 MAPK inhibitor, $\mathrm{SB} 203580$ in $0.5 \mathrm{ml}$ saline $30 \mathrm{~min}$ prior to establishing CPB and demonstrated that the pre-treatment not only significantly reduced the mRNA and protein level of TNF- $\alpha$ in lung tissue compared with those in rats undergoing $\mathrm{CPB}$ without adminis- tration of the inhibitor, but also attenuated lung tissue water and CPB-mediated damage (28). However, the expression of other proinflammatory cytokines, including IL-1 $\beta$ is also significantly reduced by the inhibitor. In addition, the p38 MAPK inhibitor affects the activity of nuclear factor (NF) $-\kappa \mathrm{B}$, which is also a TNF- $\alpha$ transcription factor but with less specificity (28). Thus, it appears that inhibition of TNF- $\alpha$ transcription factors may induce a global effect on inflammatory reactions during CPB. The possible clinical application of such inhibitors remains inconclusive.

Inhibition of TNF- $\alpha$ activity. Functional neutralizing antibodies against TNF- $\alpha$ appear to be a more specific strategy for inhibiting TNF- $\alpha$ activity compared with the inhibition of TNF- $\alpha$ transcription. Qi et al (11) and Yu et al (12) demonstrated that in a rabbit model of CPB, neutralizing antibody against TNF- $\alpha$ 


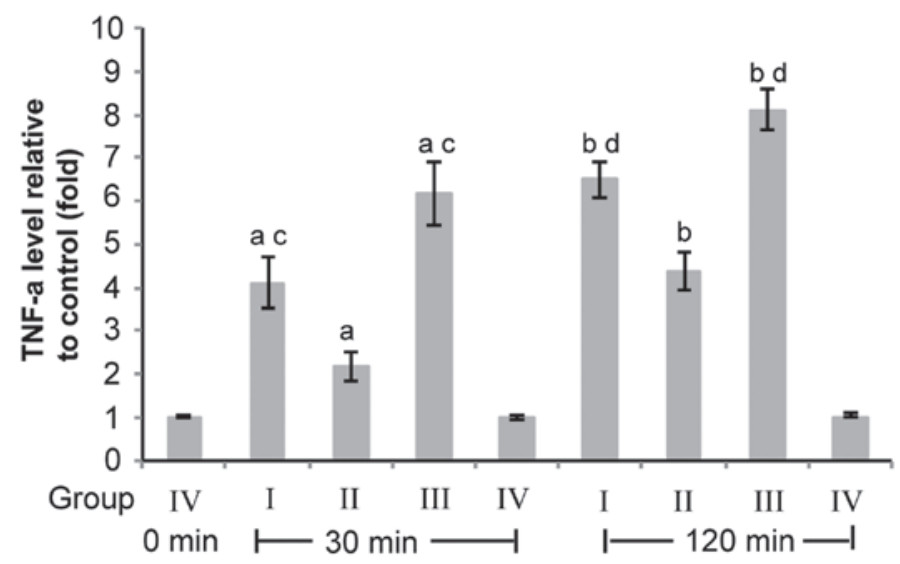

Figure 2. Pulmonary artery perfusion with TNF- $\alpha$ Ab reduces CPB-induced TNF- $\alpha$ overexpression in lung tissue. Group I, CPB+perfusion buffer; Group II, CPB+TNF- $\alpha$ Ab; Group III, CPB only; Group IV, Open heart no CPB. Rabbit lung tissues were collected following CPB for 30 and 120 min for group I-III or following the chest being opened for 30 and 120 min for group IV. $\beta$-actin was used as the reference gene. TNF- $\alpha$ level was normalized to the reference gene in each sample. The TNF- $\alpha$ level relative to that of the rabbits in group IV was calculated using the equation $2^{\Delta \Delta C T}(\mathrm{n}=10)$. Data are presented as the mean \pm standard deviation. ${ }^{a} \mathrm{P}<0.05$, group I, II and III vs. group IV for $30 \mathrm{~min}$; ${ }^{\mathrm{b}} \mathrm{P}<0.05$, group I, II and III vs. group IV for $120 \mathrm{~min}$; ${ }^{\mathrm{C}} \mathrm{P}<0.05$, group I and III vs. group II for $30 \mathrm{~min} ;{ }^{\mathrm{d}} \mathrm{P}<0.05$, group I and III vs. group II for $120 \mathrm{~min}$ (12). TNF- $\alpha$, tumor necrosis factor- $\alpha$; CPB, cardiopulmonary bypass; TLR, toll-like receptor; Ab, antibody.
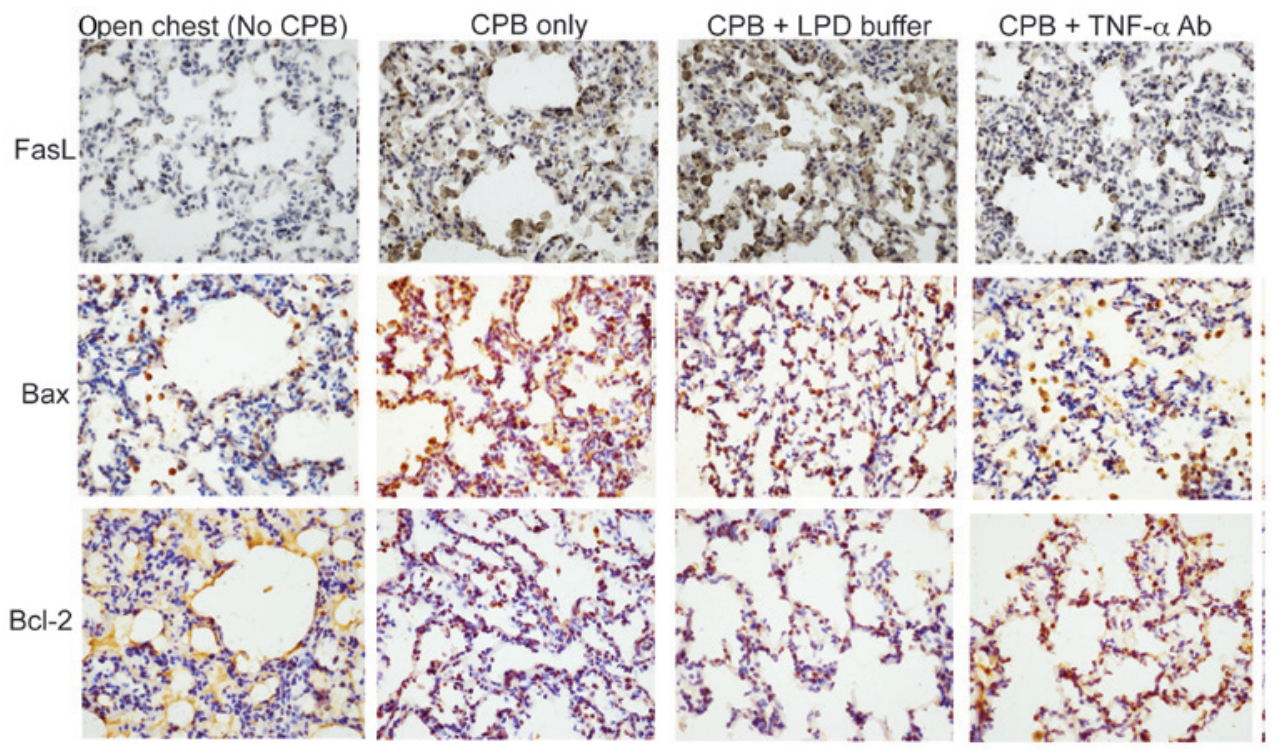

Figure 3. Pulmonary artery perfusion with TNF- $\alpha$ Ab reduces CPB-induced pulmonary apoptosis. Expression of FasL and Bax were significantly increased and the level of Bcl-2 was decreased in alveolar epithelial cells of the rabbits undergoing CPB for 30 min compared with the rabbits without CPB. By contrast, the rabbits that underwent CPB and received pulmonary artery perfusion with TNF- $\alpha$ Ab exhibited significantly less FasL and Bax expression and higher $\mathrm{Bcl}-2$ expression compared with the rabbits that underwent CPB without TNF- $\alpha$ Ab (12). Magnification, $\mathrm{x} 400$. Protein expression visualized using immunohistochemical staining. TNF- $\alpha$, tumor necrosis factor- $\alpha$; CPB, cardiopulmonary bypass; Bcl-2, B-cell lymphoma 2; Bax, Bcl-2-associated X protein; FasL, Fas ligand; $\mathrm{Ab}$, antibody; LPD, low potassium dextran lung preservation solution.

administered either by endotracheal intubation or by pulmonary artery perfusion alleviates $\mathrm{CPB}$-induced pulmonary tissue damage, prevents CPB-induced lung edema, significantly improves oxygenation index and reduces CPB-induced pulmonary inflammation. In addition to reducing the serum level of TNF- $\alpha$, Yu et al demonstrated that pulmonary artery perfusion with an antibody against TNF- $\alpha$ markedly decreased TNF- $\alpha$ expression in lung tissue (Table I and Fig. 2) (11,12). Studies on ovarian cancer cells and keratinocytes revealed that TNF- $\alpha$ stimulates its own mRNA synthesis in an autocrine manner $(29,30)$. Thus, functional inhibition of TNF- $\alpha$ was able to interrupt the autocrine TNF- $\alpha$ synthesis loop and ultimately reduce TNF- $\alpha$ production. Similar to the study by
Yu et al, Szlosarek et al also demonstrated that the TNF- $\alpha$ neutralizing antibody infliximab reduces TNF- $\alpha$ mRNA level in ovarian cancer cells by inhibiting the autocrine production loop (29). Thus, functional inhibition of TNF- $\alpha$ appears to be a strategy superior to inhibition of TNF- $\alpha$ transcription factors since it not only specifically inhibits TNF- $\alpha$ activity but also reduces its production. Yu et al (12) further investigated the molecular mechanisms underlying TNF- $\alpha$ antibody-mediated attenuation of $\mathrm{PBC}$-induced lung injury. They revealed that TNF- $\alpha$ antibody administered either by endotracheal intubation or by pulmonary artery perfusion significantly reduces CPB-induced pulmonary apoptosis in a rabbit model of CPB (Fig. 3). In addition, Imai et al demonstrated that intratracheal 
anti-TNF- $\alpha$ antibody attenuates ventilator-induced lung injury in rabbits (31).

TNF- $\alpha$ has been demonstrated to bind at least two receptors, TNFRI-p55 and TNFRII-p75 (32). The extracellular domain of these receptors can be shed into the circulation as soluble TNF- $\alpha$ receptors $\mathrm{p} 55$ and $\mathrm{p} 75$. Elevation of $\mathrm{TNF}-\alpha$ level increases the levels of soluble receptors, which are generated by the cleavage of the membrane-bound TNF receptors by a metalloproteinase after TNF binds to its membrane-associated receptors (33). Elevated soluble TNF- $\alpha$ receptor concentrations have been revealed to be an indication of a systemic inflammatory response (34). The binding of the soluble receptors to TNF- $\alpha$ inhibits the biological activity and prolongs the half-life of circulating TNF- $\alpha$ (35). The inhibitory effect of soluble receptors on TNF- $\alpha$ activity has been demonstrated in an investigation into rheumatoid arthritis. Wooley et al demonstrated that a recombinant human TNF receptor, Fc-fusion protein significantly reduced the incidence and the severity of collagen-induced arthritis in mice (36). Thus, application of soluble receptors to inhibit TNF- $\alpha$ activity appears to be another rational strategy for attenuating TNF- $\alpha$-mediated lung injury during CPB.

The clinical application of antibodies against TNF- $\alpha$ and the soluble TNF- $\alpha$ receptors p55 and p75 has been extensively investigated in human diseases where TNF- $\alpha$ has a critical role in disease development and progression, including sepsis and rheumatoid arthritis. They have been assessed in clinical trials of sepsis treatment. In phase I-III clinical trials, such agents appear to be safe and non-antigenic when they are administered intravenously to septic patients. However, the results of the sepsis trials varied significantly. Thus, the efficacy of TNF- $\alpha$ antibody and the soluble TNF- $\alpha$ receptors to treat human sepsis remains inconclusive. By contrast, the application of those agents in human rheumatoid arthritis has been demonstrated to be effective. In treating arthritis, these agents appear safe, improve disease symptoms in a dose-dependent manner and markedly reduce erythrocyte sedimentation rate and C-reactive protein level, which are indicators of systemic inflammation (37). Therefore, based on the results from studies on the rabbit model of CPB demonstrating that anti-TNF- $\alpha$ antibody can significantly attenuate CPB-induced lung injury $(11,12)$ and the successful clinical application of TNF- $\alpha$ antibodies and soluble TNF- $\alpha$ receptors in human rheumatoid arthritis, it appears that anti-TNF- $\alpha$ antibodies and soluble TNF- $\alpha$ receptors could be promising therapeutic strategies for relief of the pulmonary dysfunction associated with $\mathrm{CPB}$.

\section{Effects of anti-inflammatory intervention on TNF- $\alpha$ level}

In addition to the strategies directly targeting TNF- $\alpha$, other anti-inflammatory interventions aimed at alleviating CPB-induced lung injury have been revealed to reduce TNF- $\alpha$ level. For instance, modification of artificial circuits, including heparin-coated and phosphorylcholine-coated circuits are found to significantly reduce systemic TNF- $\alpha$ level $(38,39)$. Pharmacological interventions also appear to effectively inhibit TNF- $\alpha$ production during and following CPB. Administration of corticosteroids prior to $\mathrm{CPB}$ or aprotinin following $\mathrm{CPB}$ reduces the production of $\mathrm{TNF}-\alpha$ and other proinflammatory cytokines (40), while the antibiotic agents moxifloxacin and cefuroxime, which have been demonstrated to inhibit cytokine release from monocytes and neutrophils, do not attenuate the inflammatory cytokine response to CPB (41).

Statin drugs, which are increasingly recognized as having anti-inflammatory effects, have been widely investigated for their potential protective effects on patients undergoing CPB. Morgan et al published a systematic review of clinical trials examining the clinical benefits of pre-operative prophylactic statin therapy for patients undergoing CPB (42). Although the pooled data in their review support that pre-operative treatment with statins attenuates CPB-induced release of proinflammatory cytokines, including IL- 6 , IL- 8 and TNF- $\alpha$ in patients, due to the limited number of studies and lack of rigorous study design in certain trials, the potential anti-inflammatory effects of pre-operative statin therapy remain inconclusive.

\section{Conclusion}

In the present review, the effects of CPB on TNF- $\alpha$ level in the serum and lung tissue in patients and animal models of CPB were summarized, the molecular and cellular mechanisms underlying TNF- $\alpha$-mediated lung injury during CPB were discussed and several therapeutic strategies targeting TNF- $\alpha$ to attenuate $\mathrm{CPB}$-induced pulmonary dysfunction were proposed. Although it remains to be elucidated how serum TNF- $\alpha$ level correlates with CPB-associated morbidity in patients and whether serum TNF- $\alpha$ level can predict post-CPB complications, it appears that pulmonary artery perfusion with neutralizing antibody for TNF- $\alpha$, which can specifically inhibit pulmonary TNF- $\alpha$ production and activity, may be a superior strategy to attenuate CPB-induced lung injury.

The functions of other cytokines, including IL-6, IL-8 and IL-10 must not be ignored. The production and activity of these cytokines are also significantly affected by CPB. TNF- $\alpha$ and other cytokines may act synergistically, ultimately resulting in pulmonary dysfunction during CPB. Thus, restoration of the homeostasis of proinflammatory and anti-inflammatory cytokines may be the key to reducing CPB-induced lung injury.

\section{References}

1. Stamou SC, Pfister AJ, Dangas G, et al: Beating heart versus conventional single-vessel reoperative coronary artery bypass. Ann Thorac Surg 69: 1383-1387, 2000.

2. Asimakopoulos G, Smith PL, Ratnatunga CP and Taylor KM: Lung injury and acute respiratory distress syndrome after cardiopulmonary bypass. Ann Thorac Surg 68: 1107-1115, 1999.

3. Hammermeister KE, Burchfiel C, Johnson R and Grover FL: Identification of patients at greatest risk for developing major complications at cardiac surgery. Circulation 82: 380-389, 1990.

4. Ng CS, Wan S, Yim AP and Arifi AA: Pulmonary dysfunction after cardiac surgery. Chest 121: 1269-1277, 2002.

5. Taggart DP, el-Fiky M, Carter R, Bowman A and Wheatley DJ: Respiratory dysfunction after uncomplicated cardiopulmonary bypass. Ann Thorac Surg 56: 1123-1128, 1993.

6. Wan S, LeClerc JL and Vincent JL: Inflammatory response to cardiopulmonary bypass: mechanisms involved and possible therapeutic strategies. Chest 112: 676-692, 1997.

7. Diegeler A, Doll N, Rauch T, Haberer D, Walther T, Falk V, Gummert J, Autschbach R and Mohr FW: Humoral immune response during coronary artery bypass grafting: a comparison of limited approach, 'off-pump' technique, and conventional cardiopulmonary bypass. Circulation 102 (Suppl): III95-III100, 2000.

8. Ascione R, Lloyd CT, Underwood MJ, Lotto AA, Pitsis AA and Angelini GD: Inflammatory response after coronary revascularization with or without cardiopulmonary bypass. Ann Thorac Surg 69: 1198-1204, 2000 . 
9. Matata BM, Sosnowski AW and Galiñanes M: Off-pump bypass graft operation significantly reduces oxidative stress and inflammation. Ann Thorac Surg 69: 785-791, 2000.

10. Zhang Z, Wu Y, Zhao Y, Xiao X, Liu J and Zhou X: Dynamic changes in HMGB1 levels correlate with inflammatory responses during cardiopulmonary bypass. Exp Ther Med 5: 1523-1527, 2013.

11. Qi D, Gao MX and Yu Y: Intratracheal antitumor necrosis factor- $\alpha$ antibody attenuates lung tissue damage following cardiopulmonary bypass. Artif Organs 37: 142-149, 2013.

12. Yu Y, Gao M, Li H, Zhang F and Gu C: Pulmonary artery perfusion with anti-tumor necrosis factor alpha antibody reduces cardiopulmonary bypass-induced inflammatory lung injury in a rabbit model. PLoS One 8: e83236, 2013.

13. Wan S, LeClerc JL and Vincent JL: Cytokine responses to cardiopulmonary bypass: lessons learned from cardiac transplantation. Ann Thorac Surg 63: 269-276, 1997.

14. Welters ID, Feurer MK, Preiss V, Müller M, Scholz S, Kwapisz M, Mogk M and Neuhäuser C: Continuous S-(+)-ketamine administration during elective coronary artery bypass graft surgery attenuates pro-inflammatory cytokine response during and after cardiopulmonary bypass. Br J Anaesth 106: 172-179, 2011.

15. Martínez-Comendador JM, Alvarez JR, Mosquera I, Sierra J, Adrio B, Carro JG, Fernández A and Bengochea J: Preoperative statin treatment reduces systemic inflammatory response and myocardial damage in cardiac surgery. Eur J Cardiothorac Surg 36: 998-1005, 2009.

16. Boehm J, Hauner K, Grammer J, Dietrich W, Wagenpfeil S, Braun S, Lange R and Bauernschmitt R: Tumor necrosis factor- $\alpha-863$ C/A promoter polymorphism affects the inflammatory response after cardiac surgery. Eur J Cardiothorac Surg 40: e50-e54, 2011.

17. Yoon SZ, Jang IJ, Choi YJ, Kang MH, Lim HJ, Lim YJ, Lee HW, Chang SH and Yoon SM: Association between tumor necrosis factor alpha $308 \mathrm{G} / \mathrm{A}$ polymorphism and increased proinflammatory cytokine release after cardiac surgery with cardiopulmonary bypass in the Korean population. J Cardiothorac Vasc Anesth 23: 646-650, 2009.

18. Galiñanes M, James M, Codd V, Baxi A and Hadjinikolaou L: TNF-alpha gene promoter polymorphism at nucleotide -308 and the inflammatory response and oxidative stress induced by cardiac surgery: role of heart failure and medical treatment. Eur J Cardiothorac Surg 34: 332-337, 2008.

19. Yewei X, Liya D, Jinghao Z, Rufang Z and Li S: Study of the mechanism of pulmonary protection strategy on pulmonary injury with deep hypothermia low flow. Eur Rev Med Pharmacol Sci 17: 879-885, 2013.

20. Shen Y, Wu H, Wang C, Shao H, Huang H, Jing H and Li D: Simvastatin attenuates cardiopulmonary bypass-induced myocardial inflammatory injury in rats by activating peroxisome proliferator-activated receptor $\gamma$. Eur J Pharmacol 649: 255-262, 2010.

21. Dauber IM, Parsons PE, Welsh CH, Giclas PC, Whitman GJ, Wheeler GS, Horwitz LD and Weil JV: Peripheral bypass-induced pulmonary and coronary vascular injury. Association with increased levels of tumor necrosis factor. Circulation 88: 726-735, 1993.

22. Worrall NK, Chang K, LeJeune WS, Misko TP, Sullivan PM, Ferguson TB Jr and Williamson JR: TNF-alpha causes reversible in vivo systemic vascular barrier dysfunction via NO-dependent and -independent mechanisms. Am J Physiol 273: H2565-H2574, 1997.

23. Petrache I, Verin AD, Crow MT, Birukova A, Liu F and Garcia JG: Differential effect of MLC kinase in TNF-alpha-induced endothelial cell apoptosis and barrier dysfunction. Am J Physiol Lung Cell Mol Physiol 280: L1168-L1178, 2001.

24. Wang R, Alam G, Zagariya A, Gidea C, Pinillos H, Lalude O, Choudhary G, Oezatalay D and Uhal BD: Apoptosis of lung epithelial cells in response to TNF-alpha requires angiotensin II generation de novo. J Cell Physiol 185: 253-259, 2000.
25. Faymonville ME, Pincemail J, Duchateau J, Paulus JM, Adam A Deby-Dupont G, Deby C, Albert A, Larbuisson R, Limet R, et al: Myeloperoxidase and elastase as markers of leukocyte activation during cardiopulmonary bypass in humans. J Thorac Cardiovasc Surg 102: 309-317, 1991 .

26. Tsai CS, Chen DL, Lin SJ, Tsai JC, Lin TC, Lin CY, Chen YH, Huang GS, Tsai HY, Lin FY and Li CY: TNF-alpha inhibits toll-like receptor 4 expression on monocytic cells via tristetraprolin during cardiopulmonary bypass. Shock 32: 40-48, 2009.

27. Lee JC and Young PR: Role of CSB/p38/RK stress response kinase in LPS and cytokine signaling mechanisms. J Leukoc Biol 59: 152-157, 1996.

28. Dong X, Liu Y, Du M, Wang Q, Yu CT and Fan X: P38 mitogen-activated protein kinase inhibition attenuates pulmonary inflammatory response in a rat cardiopulmonary bypass model. Eur J Cardiothorac Surg 30: 77-84, 2006.

29. Szlosarek PW, Grimshaw MJ, Kulbe H, Wilson JL, Wilbanks GD, Burke F and Balkwill FR: Expression and regulation of tumor necrosis factor alpha in normal and malignant ovarian epithelium. Mol Cancer Ther 5: 382-390, 2006.

30. Lisby S, Faurschou A and Gniadecki R: The autocrine TNFalpha signalling loop in keratinocy tes requires atypical PKC species and NF-kappaB activation but is independent of cholesterol-enriched membrane microdomains. Biochem Pharmacol 73: 526-533, 2007.

31. Imai Y, Kawano T, Iwamoto S, Nakagawa S, Takata M and Miyasaka K: Intratracheal anti-tumor necrosis factor-alpha antibody attenuates ventilator-induced lung injury in rabbits. J Appl Physiol (1985) 87: 510-515, 1999.

32. Torre-Amione G, Kapadia S, Lee J, Bies RD, Lebovitz R and Mann DL: Expression and functional significance of tumor necrosis factor receptors in human myocardium. Circulation 92: 1487-1494, 1995

33. Katsura K, Park M, Gatanaga M, Yu EC, Takishima K, Granger GA and Gatanaga T: Identification of proteolytic enzyme which cleaves human p75 TNF receptor in vitro. Biochem Biophys Res Commun 222: 298-302, 1996.

34. Lantz M, Malik S, Slevin ML and Olsson I: Infusion of tumor necrosis factor (TNF) causes an increase in circulating TNF-binding protein in humans. Cytokine 2: 402-406, 1990.

35. Kapadia S, Torre-Amione G, Yokoyama T and Mann DL: Soluble TNF binding proteins modulate the negative inotropic properties of TNF-alpha in vitro. Am J Physiol 268: H517-H525, 1995.

36. Wooley PH, Dutcher J, Widmer MB and Gillis S: Influence of a recombinant human soluble tumor necrosis factor receptor FC fusion protein on type II collagen-induced arthritis in mice. J Immunol 151: 6602-6607, 1993.

37. Cain BS, Meldrum DR, Harken AH and McIntyre RC Jr: The physiologic basis for anticytokine clinical trials in the treatment of sepsis. J Am Coll Surg 186: 337-350, 1998.

38. Yamada H, Kudoh I, Hirose Y, Toyoshima M, Abe H and Kurahashi K: Heparin-coated circuits reduce the formation of TNF alpha during cardiopulmonary bypass. Acta Anaesthesiol Scand 40: 311-317, 1996

39. Schulze CJ, Han L, Ghorpade N, Etches WS, Stang L, Koshal A and Wang SH: Phosphorylcholine-coated circuits improve preservation of platelet count and reduce expression of proinflammatory cytokines in CABG: a prospective randomized trial. J Card Surg 24: 363-368, 2009.

40. Apostolakis EE, Koletsis EN, Baikoussis NG, Siminelakis SN and Papadopoulos GS: Strategies to prevent intraoperative lung injury during cardiopulmonary bypass. J Cardiothorac Surg 5: 1, 2010.

41. Wiesner G, Braun SL, Gruber M, Gertler R, Lange R, Tassani P and Martin K: Neither moxifloxacin nor cefuroxime produces significant attenuation of inflammatory mediator release in patients exposed to cardiopulmonary bypass: a randomized controlled trial. J Antimicrob Chemother 67: 230-233, 2012.

42. Morgan C, Zappitelli M and Gill P: Statin prophylaxis and inflammatory mediators following cardiopulmonary bypass: a systematic review. Crit Care 13: R165, 2009. 